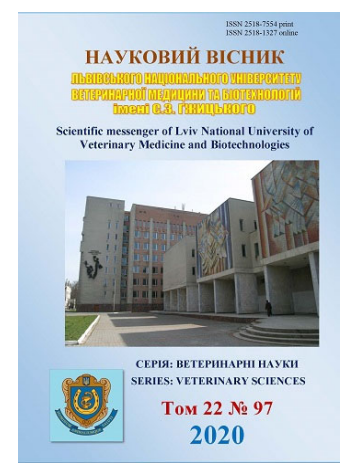

\author{
Науковий вісник Дьвівського національного університету \\ ветеринарної медицини та біотехнологій імені С.3. Гжицького. \\ Серія: Ветеринарні науки
}

Scientific Messenger of Lviv National University of Veterinary Medicine and Biotechnologies. Series: Veterinary sciences

\title{
Biochemical parameters of blood serum of dogs for ctenocephalidosis
}

\author{
K. O. Horb \\ Poltava State Agrarian Academy, Poltava, Ukraine
}

Article info

Received 20.01.2020

Received in revised form 19.02.2020

Accepted 20.02.2020

Poltava State Agrarian Academy, Skovorody Str., 1/3, Poltava, 36003, Ukraine.

Tel.:+38-050-183-78-78

E-mail: horbksenia1992@gmail.com
Horb, K. O. (2020). Biochemical parameters of blood serum of dogs for ctenocephalidosis. Scientific Messenger of Lviv National University of Veterinary Medicine and Biotechnologies. Series: Veterinary sciences, 22(97), 3-6. doi: 10.32718/nvlvet9701

One of the most common ectoparasitic diseases of domestic carnivorous animals is ctenocephalidosis caused by fleas of the genus Ctenocephalides. The peculiarity of this invasion is a chronic course associated with the constant attack of parasitic insects on the animal, accompanied by severe itching, the occurrence of alopecia, the development of eczema, dermatitis and the subsequent introduction of pathogenic microflora into the damaged tissue. The aim of the study was to investigate the effect of fleas of the genus Ctenocephalides on the biochemical parameters of the blood serum of invaded dogs. Three groups of animals were formed: a control (clinically healthy dog) and two experimental animals (infected by the parasitic insect Ctenocephalides spp.) with different intrusion rates. In blood serum determined: the content of total protein, albumin, total bilirubin, creatinine, urea, glucose, cholesterol, phosphorus, potassium, calcium, magnesium, alanine aminotransferase activity, aspartate aminotransferase, alkaline phosphate. Conducted studies found that rates the intensity of infestation significantly influence the changes that occur in blood serum infested dogs. The intensity of ctenocephalidosic infestation of up to 15 specimens of fleas in the animal in their blood serum showed a significant decrease in albumin content (by $22.37 \%$ ) compared to that in clinically healthy dogs. The intensities of xenophalphalous infestation of 16-47 specimens of fleas per animal in the serum of the infected animals showed a significant decrease in albumin (by 29.28\%), glucose (by $25.29 \%$ ), and cholesterol (by $35.59 \%$ ) relative to similar indicators clinically healthy animals. At the same time in the serum of the infested dogs the content of total bilirubin (by $15.73 \%$ ), as well as the activity of alanine aminotransferase (1.4 times), aspartate aminotransferase (1.4 times) and alkaline phosphatase (2 times). The results of the experimental data extend the already existing data on the pathogenesis of fleas parasites in dogs, and will also allow the effective treatment of diseased animals.

Key words: dogs, fleas, invasion intensity, blood serum, biochemical parameters.

\section{Біохімічні показники сироватки крові собак за ктеноцефальозу}

\author{
К. О. Горб
}

Полтавська державна аграрна академія, м. Полтава, Украӥна

Одним з найбільш поширених ектопаразитарних захворювань домашніх м'ясоїдних тварин є ктеноцефальоз, щчо викликається блохами роду Ctenосерhalides. Особливістю иієё інвазї̈ є хронічний перебіг, пов 'язаний з постійним нападом паразитичних комах на тварину, щуо супроводжується сильним свербежем, виникненням алопецій, розвитком екзем, дерматитів та подальшим занесенням патогенної мікрофлори в пошкоджену тканину. Метою роботи було вивчити вплив бліх роду Сtепосерһаlides на біохімічні показники сироватки крові інвазованих собак. Було сформовано три групи тварин: контрольна (клінічно здорові собаки) та дві дослідні (уражені паразитичними комахами Сtепосерhаlides spр.) з різною інтенсивністю інвазії. У сироватці крові визначали: вміст загального білка, альбумінів, загального білірубіну, креатиніну, сечовини, глюкози, холестеролу, Фосфору, Калію, Кальцію, Магнію, активність аланінамінотрансферази, аспартатамінотрансферази, лужної фосфатази. Проведеними дослідженнями встановлено, що показники інтенсивності інвазї значно впливають на зміни, які відбуваються у сироватці крові інвазованих собак. За інтенсивності ктеноцефальозної інвазії до 15 екземплярів бліх на тварині у сироватці їхньої крові виявлено достовірне зниження вмісту альбумінів (на 22,3 \%) порівняно з показником у клінічно здорових собак. За інтенсивності ктеноцефальозної 
інвазії 16-47 екземплярів бліх на тварині у сироватиі крові інвазованих тварин встановлювали достовірне зниження вмісту альбумінів (на 29,28\%), глюкози (на 25,29 \%) та холостеролу (на 35,59 \%) щчодо аналогічних показників у клінічно здорових тварин. Одночасно підвищувалися у сироватиі крові інвазованих собак вміст загального білірубіну (на 15,7 \%), а також активність аланінамінотрансферази (у 1,4 разу), аспартатамінотрансферази (y 1,4 разу) і лужної фосфатази (у 2 рази). Отримані результати експериментальних даних розширюють вже відомі дані стосовно патогенезу за паразитування бліх на собаках, а також дозволять ефективно проводити лікування хворих тварин.

Ключові слова: собаки, блохи, інтенсивність інвазії, сироватка крові, біохімічні показники.

\section{Встуі}

Блохи належать до паразитичних кровосисних членистоногих комах, що мають величезне значення у ветеринарії не тільки через свою патогенну дію на організм господаря, а й тому, що є переносниками різних захворювань, таких як чума, тиф, енцефаліт, гепатит, лістеріоз, дипілідіоз тощо. Найбільше значення ці комахи мають у домашніх м'ясоїдних тварин, але їх здатність використовувати як альтернативного господаря людину обумовлює значення цих паразитів і в сфері охорони здоров'я (Dryden \& Rust, 1994; Bitam et al., 2006; Blanco et al., 2006; Bitam et al., 2010).

Згідно з науковими дослідженнями, ктеноцефальоз у домашніх собак $є$ одним 3 найпоширеніших ектопаразитарних захворювань шкірного покриву тварин, яке важко піддається лікуванню і завдає значної економічної шкоди, як господарям, так і всім видам кінологічної діяльності. При укусах бліх виникає сильний свербіж, на шкірі утворюються запальні ущільнення, розвивається міліарний дерматит. Однак найбільш серйозні пошкодження тварини завдають собі самі, коли сильно розчухують i розгризають шкіряний i волосяний покрив у місцях укусів бліх. Все це призводить до утворення ділянок алопецій, екзем, дерматитів та подальшого занесення патогенної мікрофлори в пошкоджену тканину (Kwochka, 1987; Koutinas et al., 1995; Lam \& Yu, 2009).

Така алергізація організму тварин виникає як наслідок гіперчутливості на антигени слини бліх Ctenocephalides. Внаслідок укусів блоха вводить слину, яка містить більш ніж п'ятнадцять агресивних хімічних компонентів, що викликають сенсибілізацію організму тварини і призводять до розвитку дерматиту (McCall et al., 1997; Wilkerson et al., 2004; Nattoll, 2007; Overgaauw et al., 2012). Варто зазначити, що за високої інтенсивності інвазії у тварин можуть спостерігатися такі розлади, як виснаження, анемія, зниження резистентності організму. Алергічний дерматит, викликаний паразитуванням бліх, виникає у тварин незалежно від породної схильності, статі, віку. Зазвичай одним із характерних клінічних проявів $є$ помірний або сильний свербіж (Moriello et al., 1989; Carlotti \& Jacobs, 2001; Colombini et al., 2001).

Таким чином, ктеноцефальоз в собак має переважно хронічний перебіг, який обумовлений, 3 одного боку - тривалою присутністю збудника на тілі тварини, а 3 другого - періодичністю нападу паразитичних комах, що пов'язане з циклом їхнього розвитку. Тому необхідно за таких умов перебігу інвазії дослідити особливості патогенної дії бліх на організм хворих собак, а також адекватність захисних реакцій їхнього організму.

Метою роботи було вивчити вплив бліх роду Ctenocephalides на біохімічні показники сироватки крові інвазованих собак залежно від інтенсивності інвазії.

\section{Матеріал і методи досліджень}

Роботу виконували упродовж 2019 року на базі лабораторії кафедри паразитології та ветеринарносанітарної експертизи Полтавської державної аграрної академії та в умовах ветеринарного сервісу "Vetexpert" (м. Полтава).

Для встановлення біохімічних змін у сироватці крові інвазованих блохами тварин у досліді використовували 15 собак змішаних порід віком від 1 до 5 років, які належали мешканцям м. Полтави. 3 них були сформовані три групи тварин по 5 голів у кожній: одна контрольна (клінічно здорові собаки) та дві дослідні (уражені паразитичними комахами) з різною інтенсивністю інвазії (до 15 екз. та 16-47 екз. комах на тілі тварини). Кров для біохімічних досліджень отримували 3 променевої підшкірної вени передньої кінцівки зранку перед годівлею. Біохімічні показники сироватки крові досліджували за допомогою напівавтоматичного аналізатора "ВioChem SA" (США). Підготовку проб і визначення конкретних показників проводили згідно з інструкцією до приладу та реактивів. У сироватці крові визначали: вміст загального білка, альбумінів, загального білірубіну, креатиніну, сечовини, глюкози, холестеролу, Фосфору, Калію, Кальцію, Магнію, активність аланінамінотрансферази, аспартатамінотрансферази, лужної фосфатази, (Kondrahin et al., 2004; Levchenko et al., 2004).

Математичний аналіз отриманих даних проводили 3 використанням пакету прикладних програм Microsoft "EXCEL". Розраховували стандартне відхилення (SD) і середні значення (х). Достовірність відмінностей середніх величин у досліджуваних групах собак визначали за допомогою методики однофакторного дисперсійного аналізу, використовуючи критерій Фішера. Значення $\mathrm{P}<0,05$ вважали достовірним.

\section{Результати та їх обговорення}

Проведеними дослідженнями встановлено, що ступінь ктеноцефальозної інвазії значно впливав на зміни біохімічних показників сироватки крові хворих собак (табл. 1). 


\section{Таблищя 1}

Біохімічні показники сироватки крові собак, інвазованих Ctenocephalides spp., за різної інтенсивності інвазії $(\mathrm{n}=5, \mathrm{SD} \pm \mathrm{x})$

\begin{tabular}{|c|c|c|c|}
\hline \multirow[t]{2}{*}{ Показники } & \multirow{2}{*}{$\begin{array}{c}\text { Клінічно здорові тва- } \\
\text { рини }\end{array}$} & \multicolumn{2}{|c|}{$\begin{array}{c}\text { Дослідні групи тварин, } \\
\text { інтенсивність інвазії }\end{array}$} \\
\hline & & до 15 екз. & від 16 до 47 екз. \\
\hline Загальний протеїн, г/л & $57,00 \pm 5,20$ & $55,10 \pm 14,93$ & $54,80 \pm 8,32$ \\
\hline Альбуміни, г/л & $30,40 \pm 4,83$ & $23,60 \pm 3,51 *$ & $21,50 \pm 2,65^{* *}$ \\
\hline Білірубін загальний, мкмоль/л & $4,18 \pm 0,36$ & $4,58 \pm 0,44$ & $4,96 \pm 0,47 *$ \\
\hline Креатинін, мкмоль/л & $81,40 \pm 10,67$ & $88,60 \pm 20,86$ & $78,80 \pm 16,98$ \\
\hline Сечовина, ммоль/л & $5,25 \pm 1,37$ & $5,68 \pm 0,53$ & $6,28 \pm 0,95$ \\
\hline Глюкоза, ммоль/л & $5,06 \pm 0,72$ & $5,36 \pm 0,93$ & $3,78 \pm 0,56^{*}$ \\
\hline Холестерол, ммоль/л & $4,58 \pm 1,12$ & $3,32 \pm 0,59$ & $2,95 \pm 0,40^{*}$ \\
\hline Фосфор, ммоль/л & $1,60 \pm 0,25$ & $1,48 \pm 0,33$ & $1,39 \pm 0,40$ \\
\hline Калій, ммоль/л & $4,78 \pm 0,70$ & $4,74 \pm 0,29$ & $4,26 \pm 1,05$ \\
\hline Кальцій, ммоль/л & $2,64 \pm 0,31$ & $2,34 \pm 0,11$ & $2,43 \pm 0,26$ \\
\hline Магній, ммоль/л & $0,84 \pm 0,05$ & $0,86 \pm 0,06$ & $0,81 \pm 0,13$ \\
\hline
\end{tabular}

Примітка: *-P <0,05; **-P < 0,01 - щодо показників клінічно здорових тварин

Так, у сироватці крові хворих собак за показників інтенсивності інвазії до 15 екз. бліх на тварині встановлювали незначне достовірне зниження вмісту альбумінів на 22,37 \% (23,60 $\pm 3,51$ г/л, $\mathrm{P}<0,05)$ порівняно 3 показником у клінічно здорових собак $(30,40 \pm 4,83$ г/л). Інших достовірних змін у показниках щодо вмісту загального білка, загального білірубіну, креатиніну, сечовини, глюкози, холестеролу, Фосфору, Калію, Кальцію та Магнію в сироватці крові хворих та здорових собак не встановлено.

За показників інтенсивності ктеноцефальозної інвазії від 16 до 47 екз. в сироватці крові хворих собак встановлювали зниження вмісту альбумінів на
29,28 \% (21,50 $\pm 2,65$ г/л, Р < 0,01). Одночасно підвищувався вміст загального білірубіну на $15,73 \%$ (4,96 $\pm 0,47$ мкмоль/л, $\mathrm{P}<0,05$ проти показників у здорових $-6,34 \pm 0,11$ мкмоль/л). Також у дослідних собак виявляли достовірне зниження вмісту глюкози на $25,29 \%(3,78 \pm 0,56$ ммоль/л, $\mathrm{P}<0,05$ проти показників у здорових $-5,06 \pm 0,72$ ммоль/л) та холостеролу на 35,59\% (2,95 \pm 0,40 ммоль/л, $\mathrm{P}<0,05$ проти показників у здорових $-4,58 \pm 1,12$ ммоль/л).

Показники активності ферментів у сироватці крові інвазованих блохами собак залежали від показників інтенсивності інвазії (табл. 2).

\section{Таблиця 2}

Активність ферментів сироватки крові собак, інвазованих Ctenocephalides spp., за різної інтенсивності інвазії $(\mathrm{n}=5, \mathrm{SD} \pm \mathrm{x})$

\begin{tabular}{|c|c|c|c|}
\hline \multirow[t]{2}{*}{ Показники } & \multirow[t]{2}{*}{ Клінічно здорові тварини } & \multicolumn{2}{|c|}{$\begin{array}{c}\text { Дослідні групи тварин, } \\
\text { інтенсивність інвазії }\end{array}$} \\
\hline & & до 15 екз. & від 16 до 47 екз. \\
\hline АсАт, МО/л & $19,60 \pm 3,05$ & $21,40 \pm 4,04$ & $28,20 \pm 5,81^{*}$ \\
\hline АлАт, МО/л & $21,80 \pm 5,97$ & $25,40 \pm 2,88$ & $30,80 \pm 4,76^{*}$ \\
\hline Лужна фосфатаза, МО/л & $43,20 \pm 30,85$ & $76,20 \pm 28,00$ & $87,00 \pm 25,91 *$ \\
\hline
\end{tabular}

Примітка: * - $\mathrm{P}<0,05$ - щодо показників клінічно здорових тварин

Так, за показників інтенсивності ктеноцефальозної інвазії 15 екз. бліх на тварині достовірних змін у показниках активності ферментів не встановлено. Водночас за інтенсивності інвазії від 16 до 47 екз. у сироватці крові інвазованих собак виявляли достовірне зростання активності ферментів АсАт у 1,4 разу $(28,20 \pm 5,81 \mathrm{MO} / л, \mathrm{P}<0,05$ проти показників у здорових тварин - $19,60 \pm 3,05 \mathrm{MO} / л)$, АлАТ - у 1,4 разу $(30,80 \pm 4,76 \mathrm{MO} / л, \mathrm{P}<0,05$ проти показників у здорових $-21,80 \pm 5,97 \mathrm{MO} /$ л) та лужної фосфатази - у 2 рази $(87,00 \pm 25,9 \mathrm{MO} /$ л, $\mathrm{P}<0,05$ проти показників у здорових $-43,20 \pm 30,85 \mathrm{MO} / л)$.

Отже, отримані результати досліджень біохімічних показників сироватки крові інвазованих собак підтверджують результати морфологічних досліджень їхньої крові щодо впливу інтенсивності ктеноцефа- льозної інвазії на тяжкість гематологічних змін (Yevstafieva \& Gorb, 2019). Отримані нами дані вказують на те, що зі зростанням інтенсивності інвазії відбуваються більш глибокі зрушення у показниках сироватки крові інвазованих собак. Так, за інтенсивності інвазії до 15 екз. бліх у тварин встановлено гіпоальбумінемію, а за інтенсивності інвазії від 16 до 47 екз., окрім зниження вмісту альбумінів, виявлено збільшення вмісту загального білірубіну, зростання активності АсАт, АлАт, лужної фосфатази, а також зниження вмісту глюкози та холостеролу. Такі зміни вказують на патологічні зміни у печінці внаслідок інтоксикації організму від нападу і паразитування бліх. Також інвазовані собаки менше поїдали корму внаслідок сильного свербежу, що призводило до втрати поживних речовин. Про високу токсичність слини, 
що виділяє блоха при живленні на тварині, свідчать роботи багатьох авторів, які вказують на сенсибілізацію та інтоксикацію організму хазяїна (Wuersch et al., 2006; Zhao et al., 2006).

\section{Висновки}

Біохімічні показники сироватки крові собак за різної інтенсивності ктеноцефальозної інвазії характеризуються збільшенням загального білірубіну (на $15,73 \%$, Р < 0,05), зменшенням вмісту альбумінів (22,37-29,28 \%, Р < 0,05...0,01), глюкози (на 25,29 \%, $\mathrm{P}<0,05$ ), холестеролу (на $35,59 \%, \mathrm{P}<0,05)$, зростанням активності АсАт і АлАт (у 1,4 разу, Р < 0,05), лужної фосфатази (у 2 рази, $\mathrm{P}<0,05)$.

Перспективи подальших досліджень. Проведені дослідження обумовлюють необхідність визначення ефективності застосування різних інсектицидних препаратів, які $є$ високоефективними у боротьбі 3 ктеноцефальозом собак.

\section{References}

Bitam, I., Dittmar, K., Parola, P., Whiting, M. F., \& Raoult, D. (2010). Fleas and flea-borne diseases. International Journal of Infectious Diseases, 14(8), 667-676. doi: 10.1016/j.ijid.2009.11.011.

Bitam, I., Parola, P., De La Cruz, K. D., Matsumoto, K., Baziz, B., Rolain, J. M., Belkaid, M., \& Raoult, D. (2006). First molecular detection of Rickettsia felis in fleas from Algeria. American Journal of Tropical Medicine and Hygiene, 74(4), 532-535. https://www.ncbi.nlm.nih.gov/pubmed/16606979.

Blanco, J. R., Pérez-Martínez, L., Vallejo, M., Santibáñez, S., Portillo, A., \& Oteo, J. A. (2006). Prevalence of Rickettsia felis-like and Bartonella spp. in Ctenocephalides felis and Ctenocephalides canis from La Rioja (northern Spain). Annals of the New York Academy of Sciences, 1078(1), 270-274. doi: 10.1196/annals.1374.050.

Carlotti, D. N., \& Jacobs, D. E. (2001). Therapy, control and prevention of flea allergy dermatitis in dogs and cats. Veterinary Dermatology, 11(2), 83-98. doi: 10.1046/j.1365-3164.2000.00204.x.

Colombini, S., Hodgin, E. C., Foil, C. S., Hosgood, G., \& Foil, L. D. (2001). Induction of feline flea allergy dermatitis and the incidence and histopathological characteristics of concurrent indolent lip ulcers. Veterinary Dermatology, 12, 155-161. doi: 10.1046/j.1365-3164.2001.00243.x.

Dryden, M. W., \& Rust, M. K. (1994). The cat flea: biology, ecology and control. Veterinary Parasitology, 52(1-2), 1-19. doi: 10.1016/0304-4017(94)90031-0.

Kondrahin, I. P., Arhipov, A. V., Levchenko, V. I., Talanov, G. A., Frolova, L. A., \& Novikov, V. Je. (2004). Metody veterinarnoj klinicheskoj laboratornoj diagnotiki. KolosS, Moskva (in Russian).
Koutinas, A. F., Papazahariadou, M. G., Rallis, T. S., Tzivara, N. H., \& Himonas, C. A. (1995). Flea species from dogs and cats in northern Greece: environmental and clinical implications. Veterinary Parasitology, 58(1-2), 109-115. doi: 10.1016/0304-4017(94)00706-i.

Kwochka, K. W. (1987). Fleas and related disease. Veterinary Clinics of North America: Small Animal Practice, 17(6), 1235-1262. doi: 10.1016/s01955616(87)50001-8.

Lam, A., \& Yu, A. (2009). Overview of flea allergy dermatitis. Compendium on Continuing Education for the Practising Veterinarian, 31(5), 1-10. https://www.ncbi.nlm.nih.gov/pubmed/19517416.

Levchenko, V. I., Vlizlo, V. V., Kondrahin, I. P., Melnyk, J. L., \& Sudakov, M. O. (2004). Klinichna diagnostyka vnutrishnih hvorob tvaryn. Bilocerkivs'kyj derzhavnyj agrarnyj universytet, Bila Cerkva (in Ukrainian).

McCall, C. A., Stedman, K. E., Bevier, D. E., Kunkle, G. A., Foil, C. S., \& Foil, L. D. (1997). Correlation of feline IgE, determined by FceRI $\alpha$-based ELISA technology, and IDST to Ctenocephalides felis salivary antigens in a feline model of flea bite allergic dermatitis. Compendium on Continuing Education for the Practising Veterinarian, 19, 29-32.

Moriello, K. A., \& McMurdy, M. A. (1989). The prevalence of positive intradermal skin test reactions to flea extract in clinically normal cats. Companion Animal Practice, 19, 28-30.

Nattoll, T. (2007). Kozhnye bolezni sobak. AkvarjumPrint, Moskva (in Russian).

Overgaauw, P. A., van Duijkeren, E., Sprong, H., \& van Exel, J. C. (2012). Flea and tick control in dogs and cats. Tijdschr Diergeneeskd. 137(5), 316-320.

Wilkerson, M. J., Bagladi-Swanson, M., Wheeler, D. W., Floyd-Hawkins, K., Craig, C., Lee, K. W., \& Dryden, M. (2004). The immunopathogenesis of flea allergy dermatitis in dogs, an experimental study. Veterinary Immunology and Immunopathology, 99(3-4), 179192. doi: 10.1016/j.vetimm.2004.02.006.

Wuersch, K., Brachelente, C., Doherr, M., Reist, M., Sattler, U., Forster, U., Bertoni, G., Peel, J. E., \& Welle, M. (2006). Immune dysregulation in flea allergy dermatitis--a model for the immunopathogenesis of allergic dermatitis. Veterinary Immunology and Immunopathology, 110(3-4), 311323. doi: 10.1016/j.vetimm.2005.10.008.

Yevstafieva, V. O., \& Gorb, K. O. (2019). Vplyv ektoparazytiv rodu Ctenocephalides na gematologichni pokaznyky invazovanyh sobak. Visnyk Poltavs'koi' derzhavnoi' agrarnoi' akademii', 3, 215-220. doi: 10.31210/visnyk2019.03.29 (in Ukrainian).

Zhao, L., Jin, H., She, R., Hu, Y., Xiao, C., Yu, Y., Wang, J., Sun, F., Ng, T., Chu, S., \& Wang, B. (2006). A rodent model for allergic dermatitis induced by flea antigens. Veterinary Immunology and Immunopathology, 114(34), 285-296. doi: 10.1016/j.vetimm.2006.08.016. 